\title{
Effect of intraperitoneal insulin delivery on growth hormone binding protein, insulin-like growth factor (IGF)-I, and IGF-binding protein-3 in IDDM
}

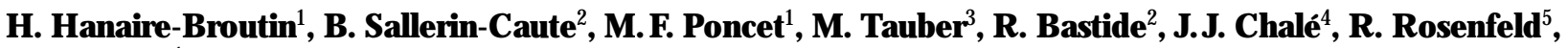 \\ J.P. Tauber ${ }^{1}$ \\ ${ }^{1}$ D epartment of D iabetology, $\mathrm{R}$ angueil U niversity $\mathrm{H}$ ospital, Toulouse, France \\ ${ }^{2} \mathrm{~L}$ aboratory of Clinical Pharmacy, Faculty of Pharmacy, Toulouse, France \\ ${ }^{3} \mathrm{~L}$ aboratory of Pediatric E ndocrinology, D epartment of Pediatric E ndocrinology, Purpan U niversity H ospital, Toulouse, France \\ ${ }^{4}$ D epartment of M edical Information, U niversity H ospital, Toulouse, France \\ ${ }^{5}$ D epartment of Pediatrics, D oembecher Children's H ospital, Portland, O regon, U SA
}

Summary Low plasma insulin-like growth factor (IGF)-I despite high circulating growth hormone $(\mathrm{GH})$ in insulin-dependent diabetes mellitus (IDD M ) indicate a hepatic G H resistance. This state may be reflected by the reduction of the circulating $\mathrm{GH}$ binding protein (GHBP), corresponding to the extracellular domain of the $\mathrm{GH}$ receptor, and the reduction of insulin-like growth factor binding protein (IG FBP)-3, major IG F-I binding protein, upregulated by $\mathrm{GH}$. We carried out two studies. In the first, plasma GHBP activity was compared in patients with ID D M on continuous subcutaneous insulin infusion (CSII) or on conventional therapy and in healthy subjects. In the second study, the 18 patients on CSII at baseline were then treated by continuous intraperitoneal insulin infusion with an implantable pump (CPII) and prospectively studied for G H-IG F-I axis. A lthough $\mathrm{HbA}_{1 \mathrm{c}}$ was lower in patients on CSII than in those on conventional therapy, GHBP was similarly reduced in both when compared to control subjects $(10.2 \pm 0.8$ and $11.6 \pm 0.9 \%$ vs $21.0 \pm 1.3, p<$ $0.01)$. CPII for 12 months resulted in: a slight and transient improvement in $\mathrm{HbA}_{1 \mathrm{c}}$ (Time ( $\mathrm{T}$ ) 0: $7.6 \pm$ $0.2 \%, \mathrm{~T} 3: 7.1 \pm 0.2 \%, \mathrm{~T} 12: 7.5 \pm 0.2 \%, \mathrm{p}<0.02)$, improvement in GHBP (T0: $10.2 \pm 0.8 \%$, T 12: $15.5 \pm$ 1.5, $p<0.0001$ ), near-normalization of IGF-I (T0: $89.4 \pm 8.8 \mathrm{ng} / \mathrm{ml}, \mathrm{T} 12: 146.9 \pm 15.6, \mathrm{p}<0.002)$ and normalization of IG FBP-3 (T 0: $1974 \pm 121 \mathrm{ng} / \mathrm{ml}$, T12: $3534 \pm 305, p<0.0001)$. The hepatic $\mathrm{GH}$ resistance profile in IDDM does not seem to be related to glycaemic control, but partly to insufficient portal insulinization. Intraperitoneal insulin delivery, allowing primary portal venous absorption, may influence GH sensitivity, and improve hepatic IGF-I and IG FBP-3 generation. [D iabetologia (1996) 39: 14981504]

Keywords Insulin-dependent diabetes mellitus, implantable pumps, insulin-like growth factor I, growth hormone binding protein, IG F binding proteins.
The relationships between the growth hormone-insulin-like growth factor-1 (G H-IG F-I) axis and diabetes mellitus are complex. $\mathrm{GH}$ has been incriminated in the development of diabetic microvascular disease,

\section{R eceived: 23 M arch 1996 and in revised form: 22 July 1996}

Corresponding author: Dr. H . H anaire-B routin, Service d'E ndocrinologie-Diabétologie, CHU R angueil, F-31054 Toulouse Cedex, France

Abbreviations: GH, Growth hormone; IGF-I, insulin-like growth factor I; G HBP, growth hormone binding protein; IG FBP-3, insulin-like growth factor binding protein 3; IP, intraperitoneal; CPII, continuous intraperitoneal insulin infusion; SC, subcutaneous; CSII, continuous subcutaneous insulin infusion. particularly retinopathy [1]. Circulating $\mathrm{GH}$ is increased in poorly controlled IDDM [2-4], whereas plasma IG F-I levels are inappropriately low $[5,6]$. Growth is impaired in children with poorly controlled insulin-dependent diabetes (IDDM) [7]. These abnormalities could reflect a resistance to $\mathrm{G} \mathrm{H}$ action, at least at the hepatic level. A high affinity $\mathrm{GH}$-binding protein (G HBP), corresponding to the extracellular domain of the $\mathrm{GH}$ receptor $[8,9]$, may provide an indirect estimate of hepatic $\mathrm{GH}$ receptor density $[10,11]$. D ecreased G HBP activity has been described in young and adult patients with IDDM [6,12-14].

The aim of this study was first, to elucidate the relationship between glycaemic control and $\mathrm{GH}$ 
Table 1. Characteristics of the three populations studied

\begin{tabular}{llll}
\hline & $\begin{array}{l}\text { G roup I } \\
\text { ID D M patients } \\
\text { on CSII }\end{array}$ & $\begin{array}{l}\text { G roup II } \\
\text { ID D M patients on } \\
\text { conventional insulin therapy }\end{array}$ & $\begin{array}{l}\text { G roup III } \\
\text { non-diabetic } \\
\text { control subjects }\end{array}$ \\
\hline $\mathrm{n}$ (male/female) & $18(11 / 7)$ & $18(11 / 7)$ & $18(11 / 7)$ \\
A ge (years) & $43.0 \pm 3.1(25-65)$ & $39.9 \pm 2.8(20-65)$ & $42.0 \pm 3.0(25-65)$ \\
B ody mass index $\left(\mathrm{kg} / \mathrm{m}^{2}\right)$ & $22.9 \pm 0.5(20-26)$ & $24.0 \pm 0.8(20.8-28)$ & $22.3 \pm 0.5(19.5-26.1)$ \\
D uration of diabetes (years) & $20.0 \pm 2.3(3-34)$ & $14.1 \pm 2.2(2-39)^{\mathrm{a}}$ & \\
Daily insulin doses (IU /day) & $39.1 \pm 2.5(20-53)$ & $39.6 \pm 2.1(24-60)$ & \\
\hline
\end{tabular}

$\mathrm{D}$ ata are mean \pm SE M (range)

${ }^{a} p<0.01$

resistance in IDDM. Second, to evaluate the impact of intraperitoneal (IP) insulin therapy, which results in preferential insulin absorption by the portal system [15], on the hepatic G H -resistant state of ID D M. To answer the first question, we compared IDDM patients on conventional insulin therapy with IDDM patients on intensified insulin therapy. To answer the second, we studied two types of intensified insulin therapy, using two modes of insulin injection: subcutaneous (SC) and IP insulin infusion.

\section{Patients and methods}

Patients. The GH-IGF-I axis was studied in two groups of patients with IDDM and in control subjects. A II the diabetic patients involved in the study were recruited and followed in the same centre, followed the same educational programme, received the same dietary recommendations, i.e. normocaloric diet containing $50 \%$ carbohydrates, and were advised to practice daily home blood glucose monitoring. Group I was composed of the 18 adult IDDM patients of our centre who were involved in the French multicentre study of the feasibility of IP insulin therapy with programmable implantable pumps in IDDM from D ecember 1991 to A pril 1992 [16]. Selection criteria included unreactive plasma C-peptide to $1 \mathrm{mg}$ glucagon, good compliance with intensive diabetes management (at least four home blood glucose tests daily [G lucometer M M emory $M$ eter, M iles, Elkart, Ind., USA ]), and adherence to treatment goals (i.e. near-normal glycaemia, avoidance of severe hypoglycaemia, and monthly clinic visits). Before implantation, they were all treated for at least 3 months by continuous SC insulin infusion (CSII) via an external pump (mean duration of treatment by CSII : $2.6 \pm 0.6$ years, range: 3 months -7.2 years), their glycated haemoglobin remaining stable during the last 3 months. These patients were then treated by continuous IP insulin infusion (CPII) via an implantable pump (MIP 2001; M inimed, Sylmar, Calif., USA ). Exclusion criteria included pregnancy, chronic renal failure and liver failure. Group II was composed of 18 adult ID D M patients with unreactive plasma C-peptide to $1 \mathrm{mg}$ glucagon, on conventional diabetes management, with two or three daily insulin injections, at least two home blood glucose tests daily, and a clinic visit every 3 months. G roup III was composed of 18 non-diabetic control subjects. The patients' characteristics are summarized in Table 1. Subjects of groups I, II, and III, were matched for age, sex and BMI. Subjects of groups I and II were also matched for insulin doses. The study was approved by the ethical committee of Toulouse, France, and informed consent was obtained from each of the subjects.

\section{Study design}

Comparison of GH-IGF-I axis in the different groups. In the first part of the study, GH and GHBP activity were compared in patients treated by CSII (group I), or SC multiple injections (group II) and in non-diabetic control subjects (group III). A II measurements, including $\mathrm{HbA}_{1 c}$ determination, were performed on the same fasting blood sample drawn at 09.00 hours for each subject.

Comparison of the effects of SC and IP insulin infusion on $\mathrm{G} \mathrm{H}$ IGF-I axis. During this second, prospective, longitudinal part of the study, the 18 patients with IDDM comprising group I, and treated at baseline by CSII, were implanted with a M inimed pump with IP catheter, and prospectively followed over 12 months. G H, G HBP activity, I GF-I, I G FBP-3, and H bA $1 \mathrm{c}$ were measured after 3 and 12 months of IP insulin therapy and compared to baseline.

\section{GH-IGF-I axis}

hG H RIA. Human (h) GH was measured using a double monoclonal antibody method (ELISA HGH; CIS-Bio International, $G$ if-sur $Y$ vette, France). The first was coated on the solid phase; the second, radiolabelled with ${ }^{125}$ I, was used as tracer. The detection limit of the assay was $0.04 \mu \mathrm{g} / \mathrm{l}$, and the intra and interassay coefficients of variation (CV) were less than 2.8 and $4.4 \%$, respectively. This $\mathrm{R} I \mathrm{~A}$ recognizes both free and $\mathrm{BP}$ bound $\mathrm{GH}$ equally.

hIGF-I RIA . IGF-I was separated from its serum carrier proteins by acid chromatography. Serum was introduced onto a Sephadex G - 50 column and eluted with $0.25 \mathrm{~mol} / \mathrm{l}$ formic acid [17]. IG F-I was measured by RIA using the IG F-I antiserum of Van Wyk and U nderwood, as previously described [18].

GHBP measurement by high pressure liquid chromatography (H PL C ). G H B P activity was measured according to the methods described by Tauber et al. [19], adapted from Tar et al. [20]. B riefly, $100 \mu$ l plasma was incubated for $22 \mathrm{~h}$ at $4^{\circ} \mathrm{C}$ with 125 hG H $\left(100 \mu l=2 \times 10^{5} \mathrm{cpm}\right.$, SB -hG H ${ }^{125} 55.5 \mathrm{kB} \mathrm{q}, \mathrm{CIS}-\mathrm{B}$ io International). A fter filtration through a $0.45 \mu \mathrm{m}$ M illipore minifilter (B edford, M ass., U SA ), $100 \mu$ l of the incubation mixture was injected into an H PL C Protein-Pak 300 SW column (Waters, $M$ ilford, M ass, U SA ; $0.75 \times 30 \mathrm{~cm}$ ). R adioactivity was recorded on a Berthold HPLC monitor LB 506 C-1 connected to a $P C$ computer (Soft B erthold 1.51 version). E ach sample was analysed, once in the presence, and once in the absence of an excess of unlabelled hG $\mathrm{H}(5 \mu \mathrm{g})$, in order to calculate specific binding. Interassay CV was $2.65 \%$. In serum containing 
$\mathrm{GH}$ levels above $7 \mathrm{ng} / \mathrm{ml}$, a correction was made, according to the result of the measurement of specific $\mathrm{GH}$ binding in serum supplemented with increasing amounts of $\mathrm{GH}$. A $n$ increase of $7 \%$ was necessary in five cases.

IG FBP-3 RIA . IG FBP-3 R IA was performed according to the method described by $G$ argosky et al. [21], adapted from B axter and $\mathrm{M}$ artin [22]. The intra and inter-assay CV s for a reference serum measured in triplicate in 12 assays were 4.4 and $12.0 \%$, respectively.

M etabolic control. G lycaemic control was assessed by $\mathrm{H} \mathrm{bA}$ using H PLC [23], in all the diabetic patients (normal range 4$6 \%$ ). Inter and intra-assay CV were 2.83 and $1.30 \%$, respectively. The patients were advised to immediately notify the medical staff of any adverse event, such as severe hypoglycaemia or ketoacidosis, as defined by the D iabetes Control and Complications Trial [24].

$D$ ata analysis. $R$ esults are expressed as mean \pm SE M . The comparisons between the three groups were done using an analysis of variance, followed by D unnett's post hoc test. This test was used for all the parameters except $\mathrm{GH}$. B ecause of the absence of equality of the variances, the comparisons for $\mathrm{GH}$ were made after logarithmic transformation, and using a non-parametric test (K ruskal and Wallis). A stepwise regression analysis was used to assess the relationships between $G H B P, G H$, IGF-I, IGFBP-3, and different patient characteristics such as age, duration of diabetes, $\mathrm{BM} \mathrm{I}$, insulin doses, $\mathrm{H} \mathrm{bA}_{1 \mathrm{c}}$. A n analysis of variance for repeated measures and a multivariate analysis of variance were performed to study the changes in G HBP, $\mathrm{GH}$, IGF-I, IG FBP-3, $\mathrm{HbA}_{1 \mathrm{c}}$ and insulin doses during CPII, and to determine the partial contributions of the various parameters (B M D P statistical software, $4 \mathrm{~V}$, univariate and multivariate analysis of variance and covariance including repeated measures)

Results

Comparison of control subjects, patients with IDDM on conventional SC therapy and patients with IDDM on CSII. Plasma G H BP activity was significantly lower in diabetic patients on CSII (group I) than in control subjects (group III) $(10.2 \pm 0.8 \%$ (range: $3.5-$ $16.5)$ vs $21.0 \pm 1.3 \%$ (range 10.4-31.6), $p<0.01$ ). There was no significant difference in G H B P activity between patients on CSII and patients on conventional insulin therapy (group II) (10.2 \pm 0.8 vs $11.6 \pm$ 0.9 (range 4.9-20.1)) (Fig. 1). B asal plasma G H levels were significantly higher in group I than in group III $(2.23 \pm 0.52$ vs $0.84 \pm 0.19 \mathrm{ng} / \mathrm{ml}, \mathrm{p}<0.05)$, and did not significantly differ between group I and group II $(2.23 \pm 0.52$ vs $1.62 \pm 0.41 \mathrm{ng} / \mathrm{ml}$ ).

$\mathrm{HbA}_{1 \mathrm{c}}$ was significantly lower in patients on CSII than in patients on conventional therapy ( $7.6 \pm 0.2$ vs $9.2 \pm 0.4 \%, p<0.01$ ).

Stepwise regression analysis showed no effect of age, B M I, duration of diabetes, insulin requirements, $\mathrm{GH}$ and $\mathrm{HbA}_{1 c}$ on $\mathrm{GHBP}$ activity. Gender was the only parameter that exerted an effect on G HBP activity (women $12.6 \pm 1.1 \%$, men $9.8 \pm 0.6 \%, r=0.39$, F level $=599$ ).
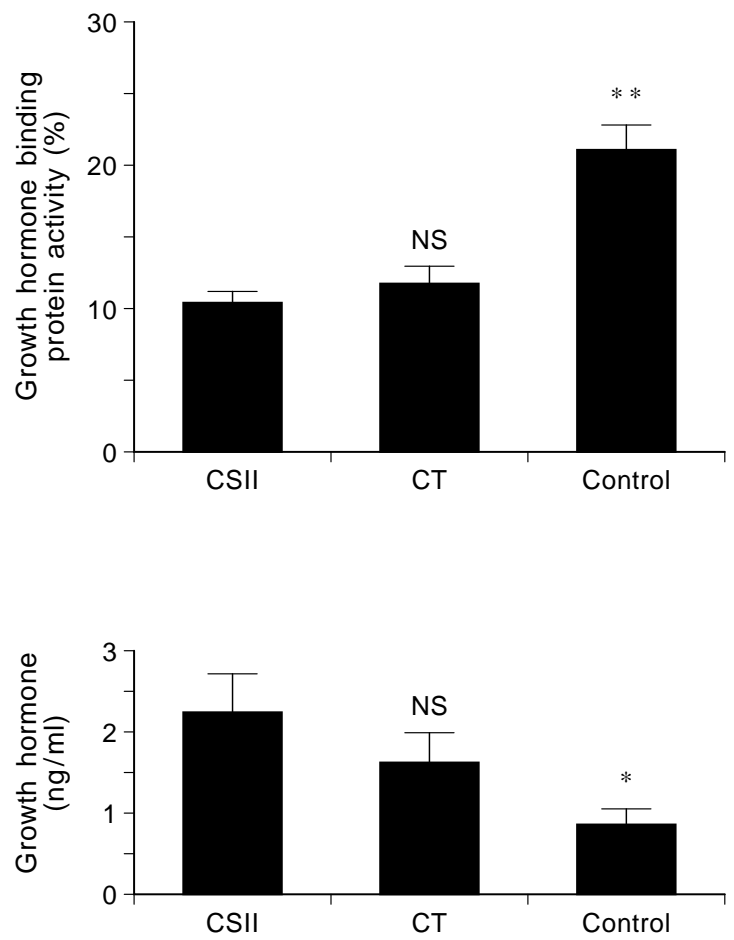

Fig. 1. Comparison of GHBP activity and of plasma basal GH concentrations in IDDM patients treated by continuous subcutaneous insulin infusion (CSII), in IDD M patients treated by conventional insulin therapy (CT), and in healthy control subjects. (mean $\pm \mathrm{SE} M$; analysis of variance)

NS: not significant; $* p<0.05 ; * * p<0.01$

Comparison of the effects of CSII and CPII on GH IGF I axis (Table 2). The analysis of variance, parameter by parameter, showed the following results: In 18 patients with IDDM treated at baseline by CSII, and then during 12 months by CPII, GHBP activity increased significantly during IP insulin therapy (T0: $10.2 \pm 0.8 \%$, T3 months: $14.5 \pm 1.1 \%$ (range 5.2-22.8), T 12 months: $15.5 \pm 1.5 \%$ (range 729.9), $p<0.0001)$, but this increase was moderate after the third month, and the values still remained below those of non-diabetic control subjects after 1 year of IP treatment $(p<0.05)$. B asal GH levels did not vary significantly throughout the study ( $T 0$ : $2.23 \pm 0.52 ; \mathrm{T} 3$ : $3.46 \pm 1.13 \mathrm{ng} / \mathrm{ml} ;$ T 12: $1.47 \pm 0.49$ $\mathrm{ng} / \mathrm{ml})$.

Plasma IGF I, low at baseline, rose steadily to reach low normal values after 1 year of CPII (T0: $89.4 \pm 4.7 \mathrm{ng} / \mathrm{ml}$ (range 51-129.6), T 3: $114.0 \pm 8.8 \mathrm{ng} /$ $\mathrm{ml}$ (range 55.7-166.6), T 12: $146.9 \pm 15.6 \mathrm{ng} / \mathrm{ml}$ (range $65.0-278.0), p<0.002$ ), the normal values ranging from 150 to $250 \mathrm{ng} / \mathrm{ml}$ in adults with this method [25]. Plasma I G F-I was normalized in 7 of the 18 patients, and never exceeded the upper limit of normal. IG FBP-3 levels were low at baseline, and increased significantly during CPII, slightly after 3 months, and markedly afterwards, reaching the normal range ( $T 0$ : $1974 \pm 121 \mathrm{ng} / \mathrm{ml}$ (range 866-2884), T3: $2275 \pm 150$ 
Table 2. G H B P activity, plasma IG F-I and I G FB P-3 in IDD M patients on CSII at (0), and after 3 and 12 months of CPII

\begin{tabular}{|c|c|c|c|c|c|c|c|c|c|c|}
\hline \multirow{2}{*}{$\begin{array}{l}\text { Patient } \\
\text { code }\end{array}$} & \multirow{2}{*}{$\begin{array}{l}\text { A ge } \\
\text { (years) }\end{array}$} & \multicolumn{3}{|c|}{ GHBP (\%) } & \multicolumn{3}{|c|}{ IGF-I (ng/ml) } & \multicolumn{3}{|c|}{ IGFBP-3 (ng/ml) } \\
\hline & & 0 & 3 months & 12 months & 0 & 3 months & 12 months & 0 & 3 months & 12 months \\
\hline 3 & 25 & 9.2 & 14.2 & 29.9 & 80.2 & 135.3 & 210 & 2232 & 1967 & 5329 \\
\hline 12 & 26 & 12.6 & 16.1 & 12.5 & 109.4 & 106.8 & 218 & 2355 & 2428 & 4522 \\
\hline 7 & 29 & 9.8 & 11.3 & 25.8 & 129.6 & 163 & 278 & 2635 & 1179 & 2412 \\
\hline 6 & 30 & 8.9 & 16.6 & 15.3 & 119 & 114.5 & 138 & 2884 & 2948 & 4265 \\
\hline 15 & 30 & 5.4 & 9.4 & 10.3 & 108.1 & 99 & 198 & 2164 & 2141 & 3383 \\
\hline 17 & 33 & 10.8 & 11.5 & 12.7 & 73 & 118 & 108 & 1752 & 1869 & 3323 \\
\hline 8 & 36 & 13.4 & 14 & 12.2 & 94.3 & 89.3 & 89.9 & 2480 & 2716 & 5381 \\
\hline 5 & 37 & 10.5 & 13.2 & 14.2 & 90.3 & 68.7 & 182.5 & 2146 & 2068 & 2625 \\
\hline 18 & 42 & 11.8 & 15.6 & 16.9 & 109 & 155 & 256 & 2276 & 2902 & 6347 \\
\hline 2 & 44 & 13.5 & 21.6 & 17.5 & 72.5 & 80.9 & 120.5 & 1871 & 1834 & 3574 \\
\hline 14 & 44 & 7.5 & 7.3 & 11.7 & 85.3 & 166.6 & 106 & 1398 & 1318 & 2329 \\
\hline 1 & 45 & 13.5 & 21 & 27 & 75.2 & 135.7 & 81 & 1962 & 2989 & 4255 \\
\hline 10 & 53 & 13 & 16 & 13.7 & 71.1 & 194 & 127 & 1782 & 2986 & 2811 \\
\hline 11 & 55 & 6.4 & 16.6 & 13.4 & 90.5 & 86.9 & 113 & 1516 & 2313 & 2248 \\
\hline 9 & 58 & 16.5 & 22.8 & 21.3 & 83.8 & 110.4 & 100.5 & 2255 & 2591 & 3713 \\
\hline 13 & 59 & 8.6 & 15.6 & 8.8 & 51 & 55.7 & 106 & 866 & 1157 & 1450 \\
\hline 16 & 63 & 8.6 & 12.3 & 9.6 & 72.4 & 88 & 147 & 1779 & 3177 & 3402 \\
\hline 4 & 65 & 3.5 & 5.2 & 7 & 93.7 & 83.2 & 65 & 1195 & 2384 & 2242 \\
\hline
\end{tabular}

$\mathrm{ng} / \mathrm{ml}$ (range 1157-3177), T12: $3534 \pm 305 \mathrm{ng} / \mathrm{ml}$ (range 1450-6347), $p<0.0001$ ) (normal values in adults $3556 \pm 508 \mathrm{ng} / \mathrm{ml}[21])$.

During treatment by $\mathrm{CPII}, \mathrm{HbA}_{1 \mathrm{c}}$ improved slightly after 3 months, but rose again afterwards (T0: $7.6 \pm 0.2 ; \mathrm{T} 3: 7.1 \pm 0.2 \% ; \mathrm{T} 12: 7.5 \pm 0.2 \%, \mathrm{p}<$ 0.02 ). Insulin doses remained unchanged throughout the study (T0: $39.1 \pm 2.5 ; \mathrm{T} 3: 40.1 \pm 3.2 ; \mathrm{T} 12: 39.4 \pm$ 3.1 IU/day), as well as BMI (T0: $22.9 \pm 0.5$, T12: $22.9 \pm 0.5 \mathrm{~kg} / \mathrm{m}^{2}$ ).

B esides these effects of time (0, 3 and 12 months), the analysis of variance showed an effect of gender on GHBP, and an absence of effect of BMI, age and duration of diabetes on all the parameters described above.

The multivariate analysis of variance, performed to determine the partial contribution of different parameters on the changes in GH, GHBP activity, I G F-I, IG FBP-3, $\mathrm{HbA}_{1 \mathrm{c}}$ and insulin doses, showed a significant effect related to gender $(p<0.006, \mathrm{H}$ otelling's T $2=5.86)$, and a significant effect of time $(0,3$, 12 months) ( $p<0.02$, H otelling's T2 $=8.68$ ), but no effect of BMI, age and duration of diabetes.

Changes in G H B P activity, plasma IG F-I and IG FBP-3 are shown in Figure 2.

A fter 1 year of CPII, G H BP did not correlate with age, $\mathrm{BM} \mathrm{I}$, duration of diabetes or $\mathrm{H} \mathrm{bA}_{1 \text {, }}$, but slightly with insulin doses $(r=0.51, F=9.22)$. There was a significant correlation between IG F-I and IGFBP-3 at baseline $(r=0,71, p<0.001)$, but not after 3 and 12 months of IP therapy.

IGF-I/IGFBP-3 ratio slightly increased after 3 months, and returned to baseline values after 12 months (T 0: $0.047 \pm 0.003$, T 3: $0.055 \pm 0.007$, T 12: $0.045 \pm 0.05, \mathrm{NS})$.

None of the patients presented with severe hypoglycaemia, ketoacidosis, or a device-related complication, nor did they require subcutaneous insulin injections.

\section{Discussion}

This study confirms inappropriately low plasma I G FI levels in IDDM, as previously described [26], suggesting a state of resistance to $\mathrm{GH}$, especially in the liver, the main source of circulating IGF-I [27, 28].We did not evaluate $24 \mathrm{~h} \mathrm{G} \mathrm{H}$ secretion, but performed a single sampling, insufficient to make conclusions about G H secretion. H owever, basal GH levels were higher in the diabetic patients than in the control subjects. The low G H B P activity found in all diabetic patients on SC insulin therapy might reflect a decrease in $\mathrm{GH}$ receptors (GHBP corresponding to the extracellular domain of $\mathrm{GH}$ receptor [29-31]), and explain a decrease in IG F-I production [32], although the role of post-receptor mechanisms is not excluded [33-35]. GHBP may be designed to maintain steady plasma $\mathrm{GH}$ levels, despite its pulsatile secretion. L ow GHBP in IDDM might increase the exposure of peripheral tissues to $\mathrm{GH}$ action during $\mathrm{GH}$ pulses.

The hepatic $\mathrm{G} \mathrm{H}$-resistance state in ID D M does not seem to be related to hyperglycaemia. G H B P activity was similar in patients on conventional SC insulin therapy and patients on CSI I, although glycaemic control was significantly better in the latter. We found no correlation between IG F-I levels and $\mathrm{HbA}_{1 c}$, or between $\mathrm{G} \mathrm{HBP}$ and $\mathrm{H}$ bA ${ }_{10}$, age or duration of diabetes in agreement with previousstudies [13, 14]. I n contrast with these studies, we found a gender-related effect, GHBP being higher in women, and no correlation between G H BP and B M I. These discrepancies might be explained by the small size of our population, 

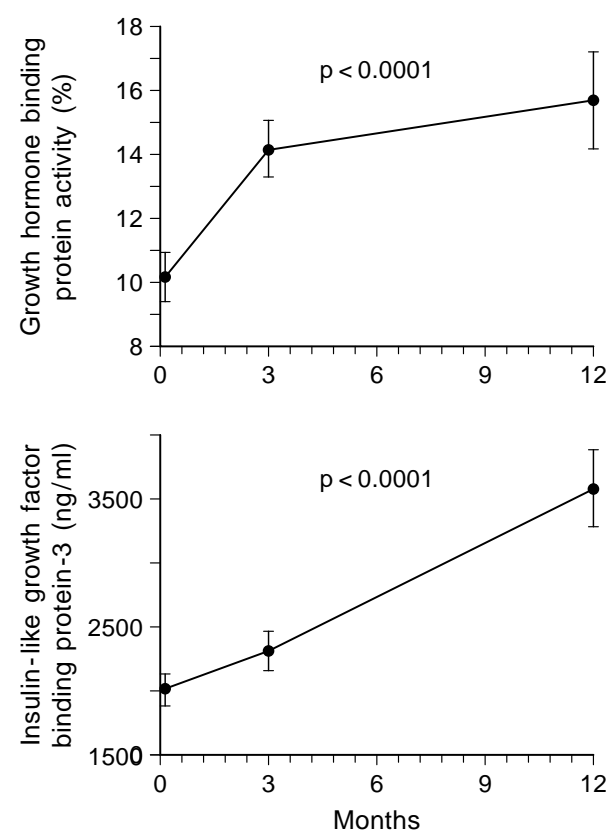

Fig. 2. Changes in GHBP activity, plasma IG F-I, plasma IG FBP-3 and $\mathrm{HbA}_{1 \mathrm{c}}$ in IDDM patients treated at baseline by continuous subcutaneous insulin infusion (CSII) and then during 12 months by continuous intraperitoneal insulin infusion (CPII). (mean \pm SE M ; analysis of variance for repeated measures)

and its homogeneity (only one of the patients was obese).

Insulin is needed for hepatic generation of IG F-I $[36,37]$. Portal insulinopenia might be responsible for $\mathrm{GH}$ resistance in ID D M [13,38]. Several studies give indirect or direct evidence of the importance of portal insulinaemia in G H sensitivity. M ercado et al. reported normal GHBP in NIDDM, in spite of high $\mathrm{HbA}_{1 \mathrm{c}}$ levels [13]. In patients with IDDM, IGF-I plasma levels induced by injections of recombinant $\mathrm{GH}$ correlate with residual $\mathrm{C}$-peptide, which reflects direct hepatic insulinization, but not with $\mathrm{HbA}_{1 \mathrm{c}}$ [39]. GHBP is low in newly diagnosed IDDM children, and its recovery after the onset of insulin therapy is determined by residual beta-cell function at diagnosis [40].

SC insulin therapy results in high systemic insulinaemia and insufficient portal insulinaemia. Therefore, SC insulin therapy, while unable to restore normal hepatic sensitivity to $\mathrm{GH}$, exposes peripheral tissues to both high levels of insulin and $G H$, which may lead to a local increase in IGF-I production, and provide one of the mechanisms of diabetic microvascular disease [38]. IP insulin delivery by implantable pumps, resulting in preferential insulin absorption by the portal system [15] and in lower peripheral levels of insulinaemia [41], might restore a
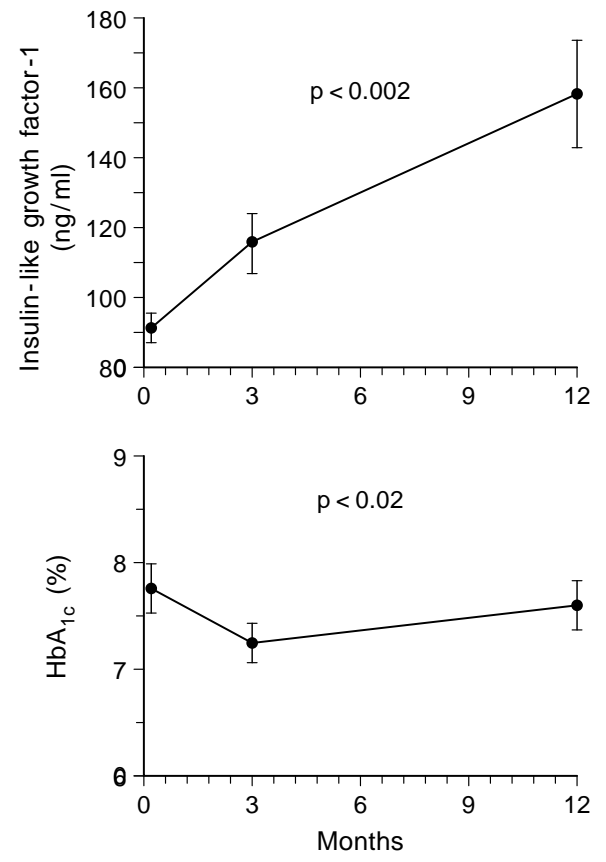

more physiological portal-to-peripheral insulinaemia ratio. In our study, this treatment slightly improved glycaemic control at first, but not in a sustained manner. N evertheless, it induced a rapid rise in G H B P activity and IG F-I plasma levels. This suggests an impact of portal insulin absorption on hepatic $\mathrm{GH}$ receptors, reflected by the rise of GHBP, resulting in an improvement in hepatic IGF-I generation. The correlation between G HBP and insulin doses during CPII suggests that the more portal insulin is increased, the more GHBP activity is restored. The great inter-individual variability was not explained by age, $\mathrm{BMI}$, or diabetes duration, and might be partIy due to genetic factors for GHBP, and other nutritional, hormonal or metabolic factors for IGF-I. G H BP activity and IG F-I levels were not totally normalized by CPII. Basal GH levels remained higher than those of the healthy control subjects. This suggests that other mechanisms may be involved in these anomalies, or that portal insulinization is only partly restored by the means of implantable pumps. We have shown that IP insulin therapy reduces the incidence rate of severe hypoglycaemic events and glycaemic fluctuations [16, 42]. A relationship between glycaemic stability and/or hypoglycaemia frequency, and $\mathrm{GH}$ sensitivity, cannot be excluded.

Of the circulating IG F-I , $80 \%$ is bound to I G F B P3 and forms a $150 \mathrm{kD}$ a ternary complex after association to the acid-labile subunit [43], that does not cross the capillary barrier, preventing IG F-I diffusion to tissues. Circulating IG FBP-3 serves as a storage pool for IG F-I [44]. I ts production is up-regulated by $\mathrm{GH}$, a direct role of IGF-I is not excluded [44, 45]. IG FBP-3 levels are decreased in poorly controlled IDDM patients [46]. This might be related to a decrease in IG FBP-3 production, and/or an increase in 
its degradation. Newly diagnosed patients with ID D M show decreased intact I G FB P-3 and increased serum I G FB P-3 protease activity [47], as previously described in situations of severe illness [48]. A fter the onset of insulin therapy, when the hypercatabolic state is over, IGFBP-3 increases and IG FBP-3 protease activity decreases, the respective role of insulin and glycaemic control not being explicit [47]. In our study, no abnormal IGFBP-3 protease activity was found in the sera of the patients, either on CSII, or on CPII (data not shown), those patients being on a normocaloric diet, and having a stable weight. Their plasma I G FBP-3 levels, low on CSII, were totally normalized by 12 months of CPII. This might reflect the effect of a better portal insulinization on $\mathrm{G} \mathrm{H}$ sensitivity. A partial role of the slight, initial improvement in glycaemic control cannot be excluded. O ther authors found that alterations in the IGF-IGFBP system could be partly accounted for by differences in metabolic control [49]. Nevertheless, one must point out that their diabetic population was very heterogeneous (untreated and treated subjects, prepubertal and pubertal), and be very careful when making conclusions about these results. The positive correlation between IG F-I and IG FBP-3 in our patients on CSII disappeared on $\mathrm{CPII}$, indicating that the regulation of these two parameters is different. CPII did not significantly increase the IG F-I/IG FB P-3 ratio. In consequence, free IGF-I levels are probably not increased, although other IGFB Ps contribute to IG F-I bioavailability. A $n$ improved portal insulinization might increase the insulin-mediated down-regulation of IGFBP-1, as previously suggested by Brismar et al. [50]. In the same study, the authors failed to demonstrate an effect of an acute intravenous insulin infusion on IG FB P-3. We cannot make comparisons between these results and ours, since insulin infusion was not IP in this case, and only acute and not chronic effects were studied.

In summary, our results suggest that IP insulin delivery, allowing primary portal venous absorption, may influence $\mathrm{GH}$ sensitivity, and improve hepatic IG F-I and IG FBP-3 generation. G lycaemic levels do not seem to play a key role in hepatic $\mathrm{GH}$ sensitivity. The influence of the insulin infusion route in patients with IDDM on IGF-I bioavailability and extra-hepatic tissue production need to be clarified by further studies.

\section{References}

1. Salardi S, Cacciari E, Ballardini D et al. (1986) Relationships between growth factors (somatomedin-C and growth hormone) and body development, metabolic control and retinal changes in children and adolescents with IDDM. Diabetes 35: 832-836

2. Hansen A P, Johansen K (1970) Diurnal patterns of blood glucose, serum free fatty acids, insulin, glucagon, and growth hormone in normals and juvenile diabetics. Diabetologia 6: 27-33

3. M erimee TJ, Fitzgerald CR, G old LA , M CC ourt J P (1979) Characteristics of growth hormone secretion in clinically stable diabetes. D iabetes 28: 308-312

4. Zadik Z, K ayne R, K appy M, Plotnick LP, Kowarski A (1980) Increased integrated concentration of norepinephrine, epinephrine, aldosterone and growth hormone in patients with uncontrolled juvenile diabetes mellitus. Diabetes 29: 655-658

5. H orner J M, Kempf SF, H intz R L (1981) G rowth hormone and somatomedin in insulin-dependent diabetes mellitus. J Clin Endocrinol M etab 53: 1148-1153

6. Clayton KL, Holly J M, Carlsson LM et al. (1994) Loss of the normal relationships between growth hormone, growth hormone-binding protein and insulin-like growth factor-I in adolescents with insulin-dependent diabetes mellitus. Clin Endocrinol 41: 517-524

7. Tattersall RB, Pyke DA (1973) Growth of diabetic children: studies in identical twins. L ancet 2: 1105-1109

8. L eung DW, Spencer SA , Cachianes G et al. (1987) G rowth hormone receptor and serum binding protein: purification, cloning and expression. N ature 330: 537-543

9. B aumann G, Shaw M A (1988) Immunochemical similarity of the human plasma growth hormone-binding protein and the rabbit liver growth hormone receptor. Biophys B iochem R es Commun 152: 573-578

10. Herrington A C, Y mer S, Stevenson J (1986) Identification and characterization of specific binding proteins for growth hormone in normal human sera. J Clin Invest 77: 1817-1823

11. B aumann G, Stolar M W, A mburn K, Barsano CP, D eV ries $B C$ (1986) A specific growth hormone-binding protein in human plasma: initial characterization. J Clin Endocrinol M etab 62: 134-141

12. Holl RW, Siegler B, Scherbaum WA, Heinze E (1993) The serum growth hormone-binding protein is reduced in young patients with insulin dependent diabetes mellitus. J Clin E ndocrinol M etab 76: 165-167

13. M ercado M, M olitch ME, Baumann G (1992) L ow plasma growth hormone binding protein in IDDM. Diabetes 41 : 605-609

14. M enon R K , A rslanian S, M ay B, Cutfield W S, Sperling M A (1992) Diminished growth hormone-binding protein in children with insulin dependent diabetes mellitus. J Clin E ndocrinol M etab 74: 934-938

15. Selam J L, B ergman R N, R accah D, J eandidier N, L ozano J, Charles M A (1990) D etermination of portal insulin absorption from peritoneum via a novel non isotopic method. Diabetes 39: 1361-1365

16. $\mathrm{H}$ anaire-Broutin $\mathrm{H}$, Broussolle $\mathrm{C}$, J eandidier $\mathrm{N}$ et al. The E VA D I A C Study Group (1995) Feasibility of intraperitoneal insulin therapy with programmable implantable pumps in ID D M . D iabetes Care 18: 388-392

17. Horner J M , Liu F, H intz R (1978) Comparison of ${ }^{125}$-somatomedin $A$ and ${ }^{125} /$-somatomedin $C$ radioreceptor assays for somatomedin peptide content in whole and acidchromatographed plasma. J Clin Endocrinol Metab 47: 1287-1291

18. Powell DR, Rosenfeld RG, Baker BK, Liu F, Hintz RL (1986) Serum somatomedin levels in adults with chronic renal failure: the importance of measuring insulin-like growth factor I (IGF-I) and IGF-II in acid-chromatographed uremic serum. J Clin E ndocrinol M etab 63: 11861192

19. Tauber M, de B ouet du Portal H, Sallerin-C aute B, R occhicioli P, Bastide $R$ (1993) Differential regulation of serum growth hormone $(\mathrm{GH})$-binding protein during continuous 
infusion versus daily injection ofrecombinant human $\mathrm{GH}$ in GH-deficient children. J Clin Endocrinol M etab 76: 11351139

20. Tar A, H ocquette J F, Souberbielle J C, C lot J P, B rauner M, Postel-Vinay MC (1990) Evaluation of the growth hormone-binding proteins in human plasma using high pressure liquid chromatography gel filtration. J Clin Endocrinol M etab 71: 470-473

21. G argosky SE, Pham HM, Wilson KF, Liu F, Giudice LC, R osenfeld RG (1992) Measurement and characterization of insulin-like growth factor binding protein-3 in human biological fluids: discrepancies between radioimmunoassay and ligand blotting. Endocrinology 131: 3051-3060

22. Baxter RC, Martin JL (1986) Radioimmunoassay of growth hormone dependent insulin-like growth factor binding protein in human plasma. J Clin Invest 78: 15041512

23. Cole R A, Soeldner J S, D unn PJ, Bunn H F (1978) A rapid method for the determination of glycosylated hemoglobins using high pressure liquid chromatography. M etabolism 27: 289-301

24. D iabetes Control and Complications Trial (DCCT) (1987) R esults of feasibility study. D iabetes Care 15: 53-58

25. R osenfeld RG, R osenbloom A L, G uevarra-A guirre J (1994) G rowth H ormone ( $\mathrm{GH}$ ) insensitivity due to primary $\mathrm{GH}$ receptor deficiency. E ndocrine $\mathrm{R}$ ev 15: 369-390

26. Tan K , B axter R C (1986) Serum insulin-like growth factor I levels in adult diabetic patients: the effect of age. J Clin E ndocrinol M etab 63: 651-655

27. D 'E rcole A J, Stiles A D, U nderwood LE (1984) Tissue concentrations of somatomedin C: further evidence for multiple sites of synthesis and paracrine or autocrine mechanisms of action. Proc $N$ atl A cad Sci U SA 81: 935-939

28. Guler H P, Zapf J, Schmid C, Froesch ER (1989) Insulinlike growth factors I and II in healthy man. E stimations of half-lives and production rates. A cta E ndocrinol 121: 753758

29. Daughaday WH, Trivedi B, A ndrews B A (1987) The ontogeny of serum $\mathrm{GH}$ binding protein in man: a possible indicator of hepatic $\mathrm{GH}$ receptor development. J Clin Endocrinol M etab 65: 1072-1074

30. B aumann G, Shaw MA, Winter RJ (1987) A bsence of the plasma growth hormone-binding protein in Laron-type dwarfism. J Clin E ndocrinol M etab 65: 814-816

31. Bick T, A mit T, B arkey R J, H ertz P, Youdim M B H, H ochberg $Z$ (1990) The interrelationship of growth hormone $(\mathrm{GH})$, liver membrane $\mathrm{GH}$ receptor, serum $\mathrm{GH}$-binding protein activity, and insulin-like growth factor I in the male rat. E ndocrinology 126: 1914-1920

32. B axter R C, B ryson J M , Turtle J R (1980) Somatogenic receptors of rat liver: regulation by insulin. Endocrinology 107: 1176-1181

33. M aes M, K etelslegers J M, Underwood LE (1983) Low plasma somatomedin $\mathrm{C}$ in streptozotocin-induced diabetes mellitus: correlation with changes in somatogenic and lactogenic liver binding sites. D iabetes 32: 1060-1069

34. R ussell-J ones D, R attray M , W ilson J V, J ones R H , Sönksen $\mathrm{PH}$, Thomas CR (1992) Intraperitoneal insulin is more potent than subcutaneous insulin at restoring hepatic insulinlike growth factor $1 \mathrm{mRNA}$ levels in the diabetic rat: a functional role for the portal vascular link. J Mol Endocrinol 3: 257-263
35. M aes M , U nderwood LE, K etelslegers J M (1986) L ow serum somatomedin $\mathrm{C}$ in insulin dependent diabetes. E ndocrinology 118: 377-382

36. D aughaday WH , Phillips L S, M ueller M C (1976) The effect of insulin and growth hormone on the release of somatomedin by the isolated rat liver. Endocrinology 98: 1214-1219

37. Scott CD, Baxter RC (1986) Production of insulin like growth factor $I$ and its binding protein in rat hepatocytes cultured from diabetic and insulin-treated diabetic rats. E ndocrinology 119: 2346-2352

38. Sönksen PH, R ussell-J ones D, Jones RH . (1993) G rowth hormone and diabetes mellitus. $\mathrm{H}$ orm $\mathrm{R}$ es 40: 68-79

39. Würtzburger MI, Prelevic GM, Sönksen PH, Ljiljana A, B alint-Peric BS, Wheeler M (1993) The effect of recombinant human growth hormone on regulation of growth hormone secretion and blood glucose in insulin-dependent diabetes. J Clin E ndocrinol 77: 267-272

40. A rslanian SA, M enon R K, G ierl A P, H eil BV, Foley J r TP (1993) Insulin therapy increases low plasma growth hormone binding protein in children with new-onset type I diabetes. Diabet M ed 10: 833-838

41. M icossi P, Cristallo M , Librenti M C et al. (1986) Free insulin profiles after intraperitoneal, intramuscular, and subcutaneous insulin administration. D iabetes Care 9: 575-578

42. B roussolle C, Jeandidier N, Hanaire-Broutin H (1994) French multicenter experience of implantable insulin pumps. Lancet 343: 514-515

43. B axter R C, M artin J L, B eniac VA (1989) High molecular weight insulin-like growth factor binding protein complexes: purification and protein properties of the acid-labile subunit from human serum. J Biol Chem 264: 1184311848

44. Thissen J P, K etelslegers J M , U nderwood LE (1994) N utritional regulation of the insulin-like growth factors. E ndocrine R eviews 15: 80-101

45. Cohen P, Fielder PJ, H asegawa Y, Frisch H, Giudice LC, Rosenfeld RG (1991) Clinical aspects of insulin-like growth factor binding proteins. A cta E ndocrinol 124: 74-85

46. B ach L A , R echler M (1992) Insulin-like growth factors and diabetes. D iabetes M etab R ev 8: 229-257

47. B ereket $A, L$ ang $C H$, B lethen $S L$, Fan J, Frost $R A$, Wilson TA (1995) Insulin like growth factor protein-3 proteolysis in children with insulin dependent diabetes mellitus: a possible role for insulin in the regulation of IG FB P-3 protease activity. J Clin Endocrinol M etab 80: 2282-2288

48. D avies SC, Wass JA H, R oss R J M, et al. (1991) The induction of a specific protease for insulin-like growth factor binding protein- 3 in the circulation during severe illness. J Endocrinol 130: 469-473

49. Strasser-Vogel B, B lum WF, Past R et al. (1995) Insulin like growth factor (IGF)-I and II and IG F-binding proteins-1, 2, and -3 in children and adolescents with diabetes mellitus: correlation with metabolic control and height attainment. J Clin E ndocrinol M etab 80: 1207-1213

50. B rismar K, Fernqvist-Forbes E, Wahren J, Hall K (1994) $E$ ffect of insulin on the hepatic production of insulin-like growth factor-binding protein-1 (IG F B P-1), IG FBP-3, and IG F-I in insulin-dependent diabetes. J Clin Endocrinol Metab 79: 872-878 